\title{
Metals, Metalloids and Toxicity in Date Palms: Potential Environmental Impact
}

\author{
John R. Williams ${ }^{1}$, Avin E. Pillay ${ }^{2}$ \\ ${ }^{1}$ Williams Analytical Chemistry Consultancy Services, Goole, UK; ${ }^{2}$ Department of Chemistry, The Petroleum Institute, Abu Dhabi, \\ United Arab Emirates. \\ Email: jrwwaccs@yahoo.co.uk
}

Received February $2^{\text {nd }}, 2011$; revised March 16 ${ }^{\text {th }}, 2011$; accepted April 25 ${ }^{\text {th }}, 2011$.

\begin{abstract}
This paper summarizes our studies on metal and metalloid uptake by the date palm, Phoenix dactylifera L., a tree of considerable importance in arid regions. The typical concentrations of 17 elements in the date palm are summarized and compared with existing data in the scientific literature. The role and toxicity of these elements are considered. Issues encountered by us during sample collection, pre-treatment and chemical analysis are described. Future studies are suggested.
\end{abstract}

Keywords: Date Palm, Metalloids, Metals, Toxicity

\section{Introduction}

The date palm, Phoenix dactylifera L., is a tree of considerable agricultural, cultural, economic and scientific importance in arid regions such as the Middle East. To quote Al-Shayeb et al. [1]: It occurs over large areas, usually growing by roadsides in industrial, rural, residential and agricultural areas even where high levels of pollution exist. It can survive within a wide temperature range, and will grow in almost any type of soil [2]. It is an evergreen plant [3]. Dates constitute a substantial part of the diet in Arab States [4]. There are over 400 different cultivars, but only 50 - 60 are grown over large areas and considered of economic value [5]. Dates are synonymous with the Middle East, but are grown in other parts of the world such as the United States of America $[6,7]$. The date palm has been used as a biomonitor of pollutants in Saudi Arabia [1], Turkey [8], Kuwait [9] and Jordan [10].

The fruiting season spans a period of about five months, roughly between May and September. With the Fard cultivar, for example, there are the Kimri (9 weeks after pollination), Bisir (15 weeks after pollination) and Rutab (20 weeks after pollination) stages of development. Usually, it is the Rutab fruit that is harvested and eaten by humans. The dates are also eaten by insects, birds and livestock. The leaflets, however, are consumed by insects and livestock. Consequently, it is vital to monitor toxic elements in dates and leaflets, and alert of current dan- gers and potential problems as early as possible.

At this stage, it is useful to introduce some definitions. In plants, toxicity is defined as the ability of a substance or element to disrupt the normal functions of a plant [11]. The toxic levels and effects of common elements are well known. As an illustration, a frequent symptom of metal toxicity in plants is chlorosis, which is a light green to yellow coloration of leaves or whole plants [11]. The data becomes scant for more exotic elements. Accumulation is where metal levels in the plant tissues are greater than in the soil or when the concentration of metals in the plant tissues increases with time [12]. Indication is when the metal levels in the plant reflect or are similar to the concentrations in the soil [12]. Alternate bearing is when the palms produce good crops of dates in some years followed by poor crops [13]. The units of concentration given in the chemical literature vary widely and the following may be useful to help avoid confusion: $1 \mathrm{ppm}=1$ $\mathrm{mg} \cdot \mathrm{kg}^{-1}=1 \mu \mathrm{g} \cdot \mathrm{g}^{-1}=1000 \mathrm{ppb}=1000 \mathrm{ng} \cdot \mathrm{g}^{-1}=1000$ $\mu \mathrm{g} \cdot \mathrm{kg}^{-1}$. It is important to note that the concentrations of elements in plant material and soil given in this paper are on a dry mass basis, except where stated otherwise.

This paper summarizes the research studies of the two authors. Our continued research in this area has drawn attention to the presence and concentration of 17 elements (13 metals, 3 metalloids and one non-metal) in Omani date palm tissues and the surrounding Haplic Torriarents soil, and the potential consequences if these elements reach toxic levels. The efforts of other research 
groups have been included in the paper to put our results in context and to encourage debate. Chemical analysis was by inductively coupled plasma-atomic emission spectroscopy (ICP-AES), except where stated otherwise.

\section{Metals}

\subsection{Silver (Ag)}

Ag has no known metabolic function and may be highly toxic towards algae and other organisms $[14,15]$. It is more toxic than $\mathrm{Pb}$, but less toxic than $\mathrm{Cd}[16,17]$. Little is known about the toxic effects of $\mathrm{Ag}$ in the date palm, but attempts have been made to obtain baseline levels in two contrasting studies. Egyptian dates were found to contain $\mathrm{Ag}$ at a concentration of $4 \mathrm{ppb}$ [18]. Six years later in a more extensive study [19], Omani dates were

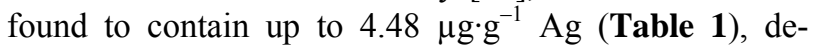
pending on fruit growth stage and the alternate bearing effect. This three orders of magnitude difference is worth investigating further. Interestingly, Ag was not detected in the leaflets, but was present in the soil at an average concentration of $1.03 \mu \mathrm{g} \cdot \mathrm{g}^{-1}$ [19].

\subsection{Aluminium (Al)}

In humans, $\mathrm{Al}$ is known to cause brain damage, bone disease and anemia in patients subjected to haemodialysis using water containing $0.1-1 \mu \mathrm{g} \cdot \mathrm{g}^{-1}$ of $\mathrm{Al}$ [20]. Al in plants at toxic levels causes stunting, dark green leaves, purpling of stems, death of leaf tips and damage to the root system [11]. Al has been studied in the date palm twice. In 1999, Al in Egyptian dates was investigated [18]. It was found that Al levels were normal and varied from 33.32 - $43.92 \mathrm{ppm}$, depending on the sample and chemical analysis method chosen. In a later study on Omani date palms, the authors considered the leaflets and surrounding soil, as well as the dates [19]. It was found that $\mathrm{Al}$ levels in the date palm tissues were, generally, safe and within literature guidelines [21]. An exception was $\mathrm{Al}$ in dates in the Kimri stage. The upper limit of $166 \mu \mathrm{g} \cdot \mathrm{g}^{-1}$ was higher than the literature value of 140 $\mu \mathrm{g} \cdot \mathrm{g}^{-1}$ (Table 1).

\subsection{Barium (Ba)}

Little is known about the toxic effects of the trace element, $\mathrm{Ba}$, in plants. However, a concentration of 500 $\mathrm{mg} \cdot \mathrm{kg}^{-1}$ in mature leaf tissue is considered excessive [11]. Ba may have been involved in the reduction of coniferous forests in parts of Europe [12]. Ba has been investigated in the date palm in two studies. In 1999, Ba was found in Egyptian dates at a concentration of 4 ppm [18]. A similar result (Table 1) was obtained six years later for Omani dates [19]. Interestingly, Ba levels in the Omani dates increased with time from an average of $0.74 \mu \mathrm{g} \cdot \mathrm{g}^{-1}$ in the Kimri stage to $2.74 \mu \mathrm{g} \cdot \mathrm{g}^{-1}$ in the Bisir stage to 12.9 $\mu \mathrm{g} \cdot \mathrm{g}^{-1}$ in the Rutab stage [19]. Previously, it was thought that plants did not accumulate $\mathrm{Ba}$. As an illustration, there was relatively little accumulation of $\mathrm{Ba}$ by macrofungi growing on uranium mill tailings [22]. It was found, however, that $\mathrm{Ba}$ levels in the dates and leaflets were safe and within the normal range of $10-100 \mathrm{mg} \mathrm{kg}^{-1}$ for plant material [11].

\subsection{Beryllium (Be)}

$\mathrm{Be}$ is one of the more poisonous elements. Its most unpleasant effect is berylliosis, and the subsequent lung fibrosis and pneumonitis, which may develop after a latency period of up to 20 years [23]. Exposure to $\mathrm{Be}$, a hypersensitising agent, also causes ulcers and skin granulomas. Little is known about the effect of Be in plant tissues, but a concentration of $0.001 \mathrm{mg} \cdot \mathrm{kg}^{-1}$ is described as normal [11]. In the two investigations performed on this metal in the date palm, contrasting results were obtained. In the first study, Be was found in Egyptian dates at a concentration of $0.4 \mathrm{ppm}$ [18]. This was 400 times the normal value. In the later investigation in Oman, Be was not detected in the fruit [19]. Furthermore, it was not detected in the leaflets either (Table 1), but was present

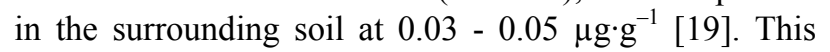
difference in the results should be investigated further.

\subsection{Cadmium (Cd)}

$\mathrm{Cd}$ is highly toxic with long term effects on kidney function and bone metabolism, and it is carcinogenic [24]. It occurs in nature in association with $\mathrm{Zn}$ minerals. Symptoms of $\mathrm{Cd}$ toxicity in plants include brown margins to leaves, chlorosis, reddish veins and curled leaves, and brown stunted roots [11]. Growing plants acquire $\mathrm{Zn}$ and they also absorb $\mathrm{Cd}$ with a similar biochemical function $[11,20,25]$. Some of the $\mathrm{Cd}$ in plants and fruit are ingested by animals and insects. Part of this ingested metal accumulates in their organs and the rest is excreted. However, excessive uptake replaces $\mathrm{Zn}$ at key enzymatic sites, causing metabolic disorders [20]. The acceptable level for $\mathrm{Cd}$ in most fruits and some edible leafy plants is about $50 \mathrm{ng} \cdot \mathrm{g}^{-1}$ [11]. The source of $\mathrm{Cd}$ in plants is usually phosphate fertilisers which contain ionic $\mathrm{Cd}$ as a contaminant, and sewage sludge which is used for soil enhancement [20,21,23,26]. There have been several studies on Cd in the date palm. In 1996, a Turkish group investigated the date palm as a biomonitor of $\mathrm{Cd}$ [8]. They found a good correlation between the concentration of $\mathrm{Cd}$ in the surface soil and in washed leaflets. A year later, the content of $\mathrm{Cd}$ in dates was investigated [27]. It was concluded that the $\mathrm{Cd}$ concentration was within the limits specified by relevant legal standards. In 1999, Cd was detected in Egyptian dates at concentrations of 15.5 - 
Table 1. A summary of the measured and recommended concentrations of 17 elements, as well as their upper limits, in Omani date palms. $\mathrm{D}=$ dates, $\mathrm{L}=$ leaflets, $[\mathrm{]}$ = reference, $\mathrm{ND}=$ not detected, $\mathrm{NA}=$ not available.

\begin{tabular}{|c|c|c|c|}
\hline Element & Mean measured conc. & Upper limit measured conc. & Recommended conc. \\
\hline \multirow{2}{*}{ Ag } & $D 0.60 \mu g \cdot g^{-1}[19]$ & D $4.48 \mu \mathrm{g} \cdot \mathrm{g}^{-1}[19]$ & $0.2 \mathrm{mg} \cdot \mathrm{kg}^{-1}[11]$ \\
\hline & L ND [19] & L ND [19] & \\
\hline \multirow{2}{*}{ Al } & D $15.2 \mu \mathrm{g} \cdot \mathrm{g}^{-1}[19]$ & D $166 \mu \mathrm{g} \cdot \mathrm{g}^{-1}[19]$ & $140 \mu \mathrm{g} \cdot \mathrm{g}^{-1}[21]$ \\
\hline & L $32.2 \mu \mathrm{g} \cdot \mathrm{g}^{-1}[19]$ & L $75.8 \mu \mathrm{g} \cdot \mathrm{g}^{-1}[19]$ & \\
\hline As & L 175 ng g $^{-1}[33]$ & L 800 ng g $^{-1}[33]$ & $80{\mathrm{ng} \cdot \mathrm{g}^{-1}[21]}$ \\
\hline \multirow{2}{*}{ B } & D $3.3 \mathrm{mg} \cdot \mathrm{kg}^{-1}$ [53] & D $6.5 \mathrm{mg} \cdot \mathrm{kg}^{-1}[53]$ & 10 - 20 ppm [11] \\
\hline & L 2.5 mg.kg ${ }^{-1}[53]$ & L 5.7 mg.kg ${ }^{-1}$ [53] & \\
\hline \multirow{2}{*}{ Ba } & D $5.0 \mu \mathrm{g} \cdot \mathrm{g}^{-1}[19]$ & D $21.0 \mu g \cdot g^{-1}[19]$ & $10-100 \mathrm{mg} \cdot \mathrm{kg}^{-1}[11]$ \\
\hline & L $3.1 \mu g \cdot g^{-1}[19]$ & L $11.3 \mu \mathrm{g} \cdot \mathrm{g}^{-1}[19]$ & \\
\hline Be & D, L ND [19] & D, L ND [19] & $0.001 \mathrm{mg} \cdot \mathrm{kg}^{-1}[11]$ \\
\hline \multirow{2}{*}{ Cd } & D $35 \mathrm{ng} \cdot \mathrm{g}^{-1}[29]$ & 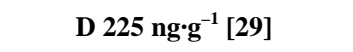 & 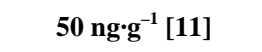 \\
\hline & 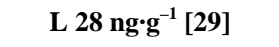 & 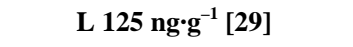 & \\
\hline $\mathrm{Cr}$ & L 2,913 ${\mathrm{ng} \cdot \mathrm{g}^{-1}[33]}$ & 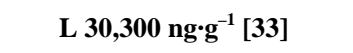 & 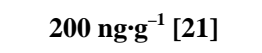 \\
\hline Ga & D,L ND [19] & D,L ND [19] & $0.1 \mathrm{mg} \cdot \mathrm{kg}^{-1}[11]$ \\
\hline Hg & L $37.2 \mu \mathrm{g} \cdot \mathrm{kg}^{-1}[37]$ & L $89.8 \mu \mathrm{g} \cdot \mathrm{kg}^{-1}[37]$ & $40 \mu \mathrm{g} \cdot \mathrm{kg}^{-1}[11]$ \\
\hline \multirow{2}{*}{ La } & D $0.41 \mu g \cdot g^{-1}[19]$ & D $4.83 \mu g \cdot g^{-1}[19]$ & NA \\
\hline & L $0.01 \mu g \cdot g^{-1}[19]$ & L $0.08 \mu g \cdot g^{-1}[19]$ & \\
\hline Mo & D,L ND [19] & D,L ND [19] & $0.1 \mathrm{mg} \cdot \mathrm{kg}^{-1}[11]$ \\
\hline \multirow{2}{*}{$\mathbf{N i}$} & D $0.28 \mu \mathrm{g} \cdot \mathrm{g}^{-1}$ [49] & D $3.98 \mu \mathrm{g} \cdot \mathrm{g}^{-1}[49]$ & $1 \mathrm{mg} \cdot \mathrm{kg}^{-1}[11]$ \\
\hline & L $0.75 \mu g \cdot g^{-1}[49]$ & L $2.20 \mu g \cdot g^{-1}[49]$ & \\
\hline \multirow{2}{*}{ Tl } & D $0.04 \mu g \cdot g^{-1}[19]$ & D $1.90 \mu \mathrm{g} \cdot \mathrm{g}^{-1}[19]$ & $0.05 \mathrm{mg} \cdot \mathrm{kg}^{-1}[11]$ \\
\hline & L ND [19] & L ND [19] & \\
\hline $\mathbf{V}$ & D,L ND [19] & D,L ND [19] & $0.1-1.0 \mathrm{mg} \cdot \mathrm{kg}^{-1}[11]$ \\
\hline Si & D,L ND [19] & D,L ND [19] & NA \\
\hline \multirow{2}{*}{ Se } & D $0.04 \mu \mathrm{g} \cdot \mathrm{g}^{-1}[19]$ & D $0.28 \mu \mathrm{g} \cdot \mathrm{g}^{-1}[19]$ & $0.05-2.0 \mathrm{mg} \cdot \mathrm{kg}^{-1}[11]$ \\
\hline & L $0.03 \mu g \cdot g^{-1}[19]$ & L $0.25 \mu g \cdot g^{-1}[19]$ & \\
\hline
\end{tabular}

$24.75 \mathrm{ppb}$, depending on the sample and chemical analysis method [18]. In 2002, Cd was reported at an average concentration of $5.65 \mu \mathrm{g} \cdot \mathrm{kg}^{-1}$ fresh weight in Saudi dates [28]. In the same year, our work in Oman [29] showed that mature dates (Bisir and Rutab) are safe for human consumption (generally below $50 \mathrm{ng} \cdot \mathrm{g}^{-1}$ ), but that levels of this heavy metal were a cause for concern earlier in the fruit growing season at the Kimri stage when concentra-

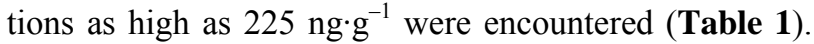
In a later study in Pakistan using atomic absorption spectroscopy, Cd levels in mature dates averaged $27 \mathrm{ng} \cdot \mathrm{g}^{-1}$ [30]. This concentration was similar to what we encountered two years earlier (Table 1). Most recently, a Saudi study concluded that $\mathrm{Cd}$ levels in dates from around $\mathrm{Ri}$ yadh were within recommended safe limits [31].

\subsection{Chromium (Cr)}

$\mathrm{Cr}$ is an essential micronutrient for animals, but not for plants [11]. $\mathrm{Cr}$ as $\mathrm{Cr}(\mathrm{VI})$ is, however, a known carcinogen [24]. At a concentration above $5 \mathrm{mg} \cdot \mathrm{kg}^{-1}$, it is toxic to plants growing in non-serpentine soils [24]. The symptoms include chlorosis of new leaves and injured root growth [11]. $\mathrm{Cr}$ in the date palm has been the subject of several studies by other workers mainly concerned with the biomonitoring of metal pollution in Saudi Arabia $[1,3,32]$ and Jordan [10]. In the case of the Saudi studies, it was discovered that $\mathrm{Cr}$ levels varied depending on whether the date palm tissues were washed or unwashed and the location. Higher Cr levels were, generally, found in unwashed plant material from urban areas. 
Similarly, the Jordanian study found that the highest $\mathrm{Cr}$ levels were present in leaflets from palms growing in urban and industrial areas. One study investigated $\mathrm{Cr}$ in Egyptian dates [18]. They found that $\mathrm{Cr}$ levels varied from 30.2 - $95 \mathrm{ppb}$, depending on the sample and the chemical analysis method employed. Our research group similarly showed that $\mathrm{Cr}$ levels in Omani dates were safe for human consumption [33]. Concentrations in leaflets were, however, a cause for concern (Table 1). According to the literature, the permissible mean level of $\mathrm{Cr}$ in plants is $200 \mathrm{ng} \cdot \mathrm{g}^{-1}$ [21]. In the case of $\mathrm{Cr}$, about $45 \%$ of the leaflet samples possessed levels between 250 and 700 $\mathrm{ng} \cdot \mathrm{g}^{-1}$, while a significant number produced levels between 1000 and $5000 \mathrm{ng} \cdot \mathrm{g}^{-1}$ [33]. There was some evidence of $\mathrm{Cr}$ accumulation in the leaflets too. This was an important finding, because insects and other organisms subsist on the leaves and there is a danger of accumulation of $\mathrm{Cr}$ in the food chain.

\subsection{Gallium (Ga)}

$\mathrm{Ga}$ is a trace element [11], but little is known about its toxic effects in plants. It has been studied in lichen and, consequently, it is known that background concentrations in this organism are $0.09-0.49 \mathrm{ng} \cdot \mathrm{g}^{-1}$ [34] and elevated levels are considered to be $0.2-2.2 \mathrm{ng} \cdot \mathrm{g}^{-1}$ [35]. A concentration of $0.1 \mathrm{mg} \cdot \mathrm{kg}^{-1}$ is a reference value considered typical in plants [11]. Ga has been studied in the date palm on two occasions. In 1999, it was found in Egyptian dates at a concentration of about $0.4 \mathrm{ppm}$ [18]. Six years later in Oman [19], Ga was found in the surrounding soil at an average concentration of $1.38 \mu \mathrm{g} \cdot \mathrm{g}^{-1}$, but was not detected in the leaflets and fruit (Table 1). The discrepancy between the 1999 and 2005 results should be investigated further.

\subsection{Mercury (Hg)}

The health effects of $\mathrm{Hg}$ are well-known. $\mathrm{Hg}$ is highly toxic, especially organomercury compounds [24]. Methylmercury, for example, is a neurotoxin and damages the nervous system [36]. $\mathrm{Hg}$ is toxic to plants at concentrations greater than $1 \mathrm{mg} \cdot \mathrm{kg}^{-1}$ [24]. Symptoms of $\mathrm{Hg}$ toxicity include severe stunting of seedlings and roots, leaf chlorosis and browning of leaf points [11]. Several studies have concentrated on $\mathrm{Hg}$ in dates from Egypt [18], Saudi Arabia [28] and Pakistan [30]. Our study in Oman focused on total $\mathrm{Hg}$ in the leaflets using a cold vapour atomic absorption method [37]. We found that, in some cases (Table 1), Hg levels were above the recommended maximum for plant leaves of $40 \mu \mathrm{g} \cdot \mathrm{kg}^{-1}$ [11]. This was of concern, because livestock are fed partly on date palm leaflets. Additionally, insects eat the leaflets and are themselves devoured by birds. The possible consequence in both cases is biomagnification of $\mathrm{Hg}$ along the food chain.

\subsection{Lanthanum (La)}

Some studies have been conducted on the health effects of $\mathrm{La}$ in animals and humans. $\mathrm{La}^{3+}$ inhibits the binding of calcium ions by muscle microsomes in dogs $[38,39]$. La increases the clotting time of normal human plasma in a dose-dependent manner when clotting was induced either by thromboplastin or by kaolin in the presence of cephalin and $\mathrm{Ca}^{2+}[40] . \mathrm{La}^{3+}$ increases the energy coupling capacity of submitochondrial particles [41]. $\mathrm{La}^{3+}$ induces cell apoptosis [42] and $\mathrm{La}$ affects the neurobehavioral development of rats $[43,44]$. There have been fewer studies in plants and just two on $\mathrm{La}$ in the date palm. The first study found La in Egyptian dates in the range 17.75 $62 \mathrm{ppb}$, depending on the sample and chemical analysis method used [18]. They also investigated $\mathrm{Ce}$ and $\mathrm{Eu}$, but these lanthanides went undetected in the dates. During the later study in Oman, it was discovered that La was only detected in the dates and leaflets during the Bisir stage [19]. At that time, La was present in the dates at an average concentration of $2.45 \mu \mathrm{g} \cdot \mathrm{g}^{-1}$ and in the leaflets at $0.07 \mu \mathrm{g} \cdot \mathrm{g}^{-1}$. When all the stages and samples are taken into account, the average levels decrease (Table 1). La was present in the soil at a mean level of $0.05 \mu \mathrm{g} \cdot \mathrm{g}^{-1}$. This data infers that the fruits were accumulating La during the Bisir stage. Furthermore, the date palm (through the leaflets during the Bisir stage) could be used as an indicator species for $\mathrm{La}$ in soil. Lanthanides, including $\mathrm{La}$, were not detected by inductively coupled plasma- mass spectroscopy (ICP-MS) in the potable water used to irrigate the date palms [45]. The large difference in La concentration in Egyptian and Omani dates should be investigated further. The remaining lanthanides and all the actinides are unstudied in the date palm. The actinides have not received attention, presumably because of their radioactivity and consequent changes in concentration with time.

\subsection{Molybdenum (Mo)}

Mo is an essential micronutrient for plants and animals [11]. A high concentration of Mo does not normally affect plants, but can pose a problem for ruminant animals, particularly dairy cows, that consume plants containing 5 $\mathrm{ppm}$ or more of the element [11]. In the one study on Mo in the date palm, it was found that the element was neither detected in the leaflets nor the fruit (Table 1) nor the surrounding soil [19]. The dates and leaflets can be recommended, therefore, as a livestock feed with respect to Mo. To alleviate any problems with the date palms due to Mo deficiency, the trees should be fed the element at a normal level of $0.1 \mathrm{mg} \cdot \mathrm{kg}^{-1}$ [11].

\subsection{Nickel (Ni)}

$\mathrm{Ni}$ is a controversial element. Some believe it to be an essential element [11], but others class it as an element of 
common environmental concern [46], because it is highly toxic and carcinogenic [24]. Ni is toxic to plants when soil $\mathrm{Ni}$ levels exceed $100 \mathrm{mg} \cdot \mathrm{kg}^{-1}$ and plant tissue $\mathrm{Ni}$ concentrations are above $10 \mathrm{mg} \cdot \mathrm{kg}^{-1}$ [24]. Toxic levels of this transition metal can cause interveinal chlorosis in new leaves, stunted foliage, and brown short roots in certain crops [11]. Several studies have been conducted on $\mathrm{Ni}$ in the date palm. In 1999, Ni was found in Egyptian dates at a concentration of $0.4 \mathrm{ppm}$ [18]. Furthermore, the fibre [32], leaflets [47] and fruit [48] of Saudi date palms have all received attention. More recently, Ni levels in date palm leaflets from Jordan have been studied [10]. Our work concentrated on $\mathrm{Ni}$ in Omani date palms grown in soil containing elevated levels of $\mathrm{Ni}$ [49]. It was found that, despite the relatively high soil Ni content (a mean of $91 \mu \mathrm{g} \cdot \mathrm{g}^{-1}$ with a range of $34-153 \mu \mathrm{g} \cdot \mathrm{g}^{-1}$ ), the date palms appeared healthy and did not accumulate $\mathrm{Ni}$ in the fruit and leaflets (Table 1). The Ni content of the fruit and leaflets was safe (below $4 \mu \mathrm{g} \cdot \mathrm{g}^{-1}$ in all cases), similar to the findings of earlier studies, and within international guidelines [21].

\subsection{Thallium (Tl)}

$\mathrm{Tl}$ is highly toxic to humans [50]. Little is known about the phytotoxicity of $\mathrm{Tl}$. In the one study conducted on $\mathrm{Tl}$ in the date palm [19], it was found that the element was present in the fruit, but not detected in the leaflets (Table 1). Tl levels in the fruit averaged $0.47 \mu \mathrm{g} \cdot \mathrm{g}^{-1}$ in the Kimri stage, but $1.04 \mu \mathrm{g} \cdot \mathrm{g}^{-1}$ in the Bisir stage. Tl was not detected in the Rutab stage, which is eaten by humans. Tl levels in plants are typically $0.05 \mathrm{mg} \cdot \mathrm{kg}^{-1}$ [11], so the $\mathrm{Tl}$ concentration in some of the fruit was high and a cause for concern. It was found that $\mathrm{Tl}$ levels in the fruit were similar to those in the soil [19], implying that low Tl-containing soil should be used for date palms grown for agricultural purposes and that the date palm could act as an indicator species for this element.

\subsection{Vanadium (V)}

$\mathrm{V}$ is a trace element and believed to be a micronutrient in animals only [11], although not all scientists share this view [51]. The toxic effects of $\mathrm{V}$ in plants are relatively unknown. The normal range in plant leaves is $0.1-1.0 \mathrm{mg}$ $\mathrm{kg}^{-1}$ with a suggested maximum of $2 \mathrm{mg} \cdot \mathrm{kg}^{-1}$ [11]. V has been investigated twice in the date palm. In the first study, $\mathrm{V}$ was found in Egyptian dates at concentrations of 0.78 $5.1 \mathrm{ppb}$, depending on the sample and the chemical analysis method utilised [18]. In a later study in Oman, V was not detected in the date palm fruit or leaflets (Table 1) despite being present in the soil at an average concentration of $0.87 \mu \mathrm{g} \cdot \mathrm{g}^{-1}$ [19]. The contrasting results of the two studies should be investigated further.

\section{Metalloids}

Metalloids, also known as semimetals, are eight elements that exhibit both metallic and non-metallic properties under certain circumstances [52]. These elements in order of atomic number are: $\mathrm{B}, \mathrm{Si}, \mathrm{Ge}, \mathrm{As}, \mathrm{Sb}, \mathrm{Te}, \mathrm{Po}$ and At. Some studies have been conducted on metalloids in the date palm by the authors of this paper. We considered As, $\mathrm{B}$ and $\mathrm{Si}$.

\subsection{Arsenic (As)}

In humans, As is highly toxic and carcinogenic [24]. It is phytotoxic when found at greater than $5 \mathrm{mg} \cdot \mathrm{kg}^{-1}$ in plant tissue [24]. Symptoms of As poisoning in plants include red-brown necrotic spots on old leaves, yellowing or browning of roots and depressed tillering [11]. Our research group investigated As in Omani date palm leaflets [33]. Appreciable levels of As were encountered in the leaflets (Table 1). This is a cause for concern, because the leaflets form a significant ingredient in livestock feed in the date-producing countries of the Middle East. About $70 \%$ of the samples were above the documented permissible mean value of $80 \mathrm{ng} \cdot \mathrm{g}^{-1}$ [21]. A year later in Pakistan, As was studied in dates using instrumental neutron activation analysis [30]. It was found that As levels in the dates were safe.

\subsection{Boron (B)}

$\mathrm{B}$ is an essential element in plants, but not in animals [11]. In humans, B appears to offer protection from prostate cancer and an intake of $3.0 \mathrm{mg} \cdot \mathrm{day}^{-1}$ is considered beneficial, but large amounts are toxic [52]. In plants, an excess of B (50 - $200 \mathrm{ppm})$ causes leaf tips to become yellow, followed by necrosis [11]. Leaves eventually assume a scorched appearance and prematurely fall off. B has been studied in the date palm [53]. Levels of B were generally $1-6 \mathrm{mg} \cdot \mathrm{kg}^{-1}$ in the dates and leaflets (Table 1), and $3-8 \mathrm{mg} \cdot \mathrm{kg}^{-1}$ in the surrounding soil. Normal B levels in plant material are $10-20 \mathrm{ppm}$ [11], so the palms were B deficient. Low levels of B (below $3.5 \mathrm{mg} \cdot \mathrm{kg}^{-1}$ ) were associated with palms that produced a poor yield of fruit. Furthermore, K/B ratios of greater than 2500 were found in these trees. It is recommended that the date palms be fed a B supplement in future.

\subsection{Silicon (Si)}

Si has been described as essential for some plants and often beneficial for others [54]. Concentrations of soluble Si range from $1-40 \mathrm{mg} \cdot \mathrm{l}^{-1}$ in soil water [55]. It has been studied in the date palm [19]. No Si was detected in the leaflets and fruit (Table 1). It was, however, found in the surrounding soil at a concentration of $3.83 \mu \mathrm{g} \cdot \mathrm{g}^{-1}$. Consequently, the date palm does not take up Si to any great 
extent and it is not an element of concern from a toxicity point of view.

\section{Non-Metals}

The only non-metal considered by the authors was selenium (Se). It is an essential micronutrient for animals, but highly poisonous at greater concentrations [24]. At levels greater than $4 \mu \mathrm{g} \cdot \mathrm{g}^{-1}$, Se can be toxic as it prevents proper bone formation in animals [55]. In plant tissue, Se is phytotoxic at concentrations exceeding $5 \mathrm{mg} \cdot \mathrm{kg}^{-1}$ [24]. Se toxicity manifests itself as interveinal chlorosis or black spots at a content of about $4 \mathrm{ppm}$, and complete bleaching or yellowing of younger leaves at higher Se concentration, and pinkish spots on roots [11]. Se has been investigated in Pakistani date palm fruits using instrumental neutron activation analysis [30]. It was found that the average concentration of Se in the dates was 75 $\mathrm{ng} \cdot \mathrm{g}^{-1}$. This is within the normal range for plants, which is $0.05-2.0 \mathrm{mg} \cdot \mathrm{kg}^{-1}$ [11]. A year later in Oman, Se was not only studied in the dates, but also the leaflets and surrounding soil [19]. It was discovered that Se was found in the fruit and leaflets (Table 1), but only during the Kimri stage. Se levels in the leaflets and fruit, when detected, were within the normal range for plants (Table 1). Consequently, Se levels in the date palm are not a cause for concern yet. Interestingly, Se was not detected in the surrounding soil, implying that the date palm was accumulating the element during the Kimri stage.

\section{Problems and Remedial Measures}

Several issues arose during our studies, mainly around sample collection, pre-treatment and chemical analysis.

\subsection{Sample Collection}

Samples should be collected from date palms all of the same age, because elemental uptake varies with age (El Mardi, personal communication). A sampling site should be chosen that is not sprayed with pesticides, which often contain metals such as $\mathrm{Hg}$ and As [24]. Pesticide use could produce misleading metal content results, since the leaflets and fruits are washed (removing surface pesticide) before chemical analysis, but the soil is not. It is particularly important to collect a representative sample for accurate results. Consequently, four strands of fruit, each from a different direction (north, south, east and west), were taken from a date palm and combined to form one sample [56]. Similarly, four leaflets per date palm from the median position along the rachis (Figure 1) were picked and united. Furthermore, three plugs of soil around the base of each palm were taken and mixed together.

Soil samples were needed in connection with accumulation and indication studies. The soil often contained

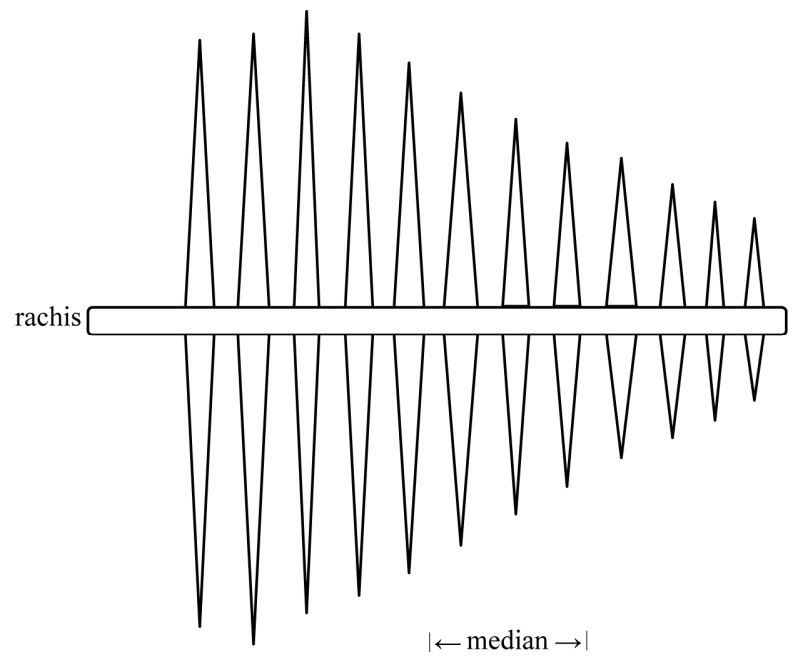

Figure 1. Date palm leaflet showing the median portion of the rachis.

many small stones. This made soil sample collection difficult, because it prevented the Auger soil sampler (Figure 2) going deeper into the soil once a stone was struck. There was no choice, but to remove the sampler from the ground and start again. Consequently, a patient approach had to be adopted. Considering that there were typically 12 palms in the study, this was arduous work in the heat of a Middle Eastern summer where outside temperatures can reach $50^{\circ} \mathrm{C}$.

Bearing in mind the heat and the physical demands of sample collection, it is advisable to obtain assistance when collecting the large number of samples needed. This usually involves employing local laborers. Since they are not scientifically trained, they need close supervision to ensure that they are collecting samples correctly. In addition, the wages of the laborers add to the overall cost of the project and this should be borne in mind when applying for research grants.

\subsection{Sample Pre-Treatment}

The large number of collected samples presents problems in the laboratory at the pre-treatment stage before chemical analysis. Dozens of soil, leaflet, and fruit samples need to be digested or ashed. This may prove prohibitive for final year undergraduate project students, who have other commitments. Consequently, a postgraduate student $(\mathrm{MSc}$ or $\mathrm{PhD})$ or postdoctoral researcher is recommended for the labor-intensive work involved.

Digestion and ashing methods should be tested on samples of known concentration such as certified reference materials (CRMs) to ascertain the efficiency of the procedure. At the time of writing, there are no date palm CRMs. Consequently, other plant CRMs have to be used instead [37]. This could be a problem, because the date 


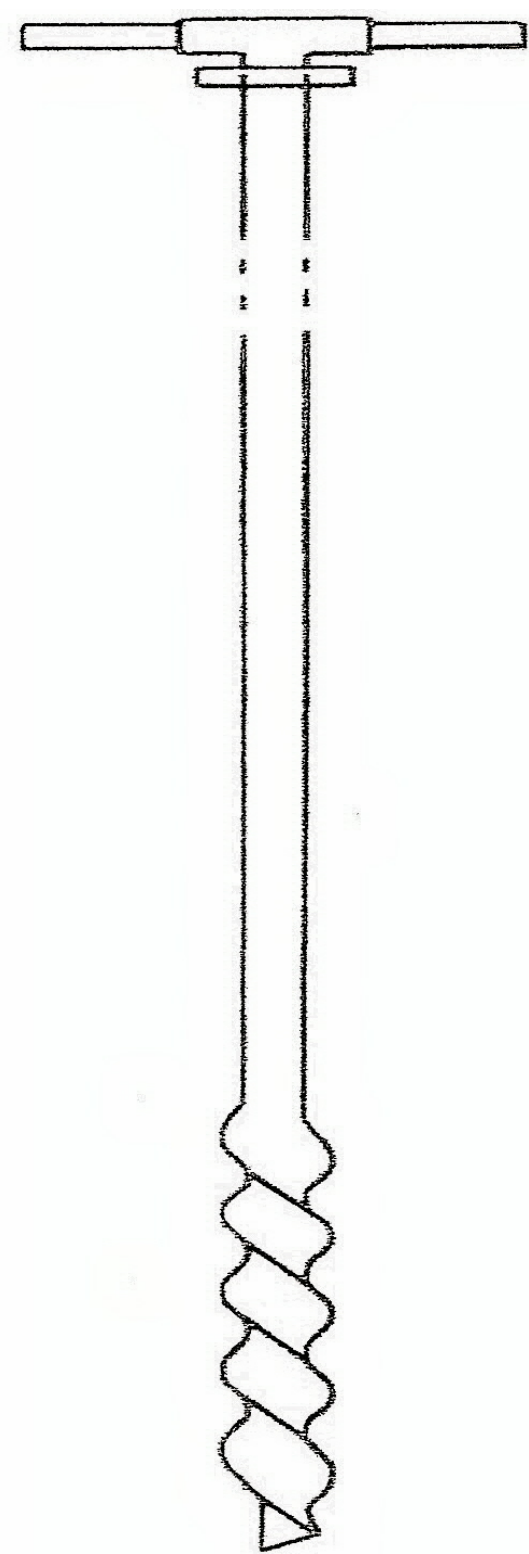

Figure 2. Soil sampler used in the study.

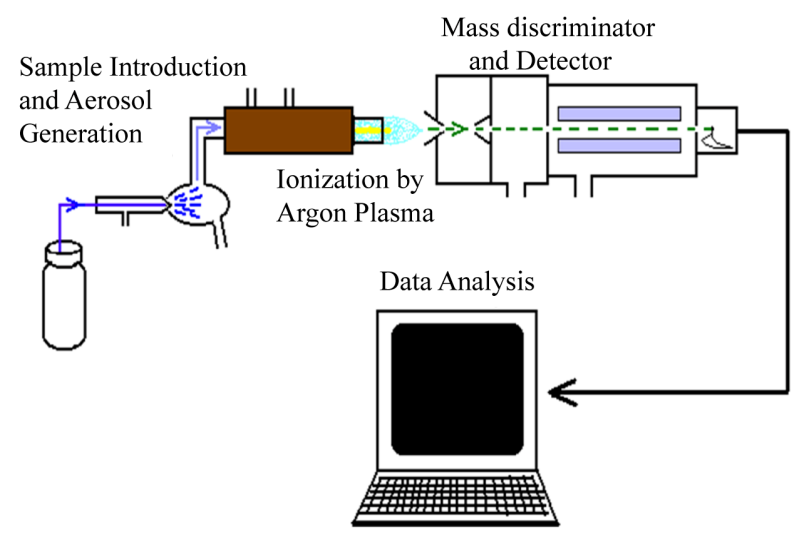

Figure 3. Schematic diagram of the ICP-MS instrument. palm is adapted for arid conditions, for example, it has tough skin on the fruit and leaflets. Other plants may not have these natural modifications and may behave differently during pre-treatment. In addition, some elements form volatile species during pre-treatment and may not be recovered quantitatively [57]. In such cases, a closed vessel is recommended during, for example, digestion.

\subsection{Chemical Analysis of Samples}

The chemical analysis of the samples can be challenging too. As stated previously, ICP-AES was used for the bulk of the chemical analysis by the authors. In some cases, for example, $\mathrm{Be}, \mathrm{Ga}, \mathrm{Mo}, \mathrm{Se}, \mathrm{Si}, \mathrm{Tl}$ and $\mathrm{V}$, the elements were not detected in some samples. It is possible that these elements were there, but present at concentrations below the detection limit of ICP-AES. Consequently, it is recommended that ICP-MS (Figure 3) be used in any future studies as the detection limit is superior [57].

\subsection{Other Issues}

Contamination of samples by the laboratory glassware can be a problem. Metals (as ions) from previous studies can adsorb to the glass surface and can contaminate new samples [57]. This contamination can be avoided by rinsing the glassware with dilute nitric acid $(1.54 \mathrm{M})$ beforehand.

\section{Future Work}

There is considerable potential for further work. On several occasions, for example with $\mathrm{Ag}, \mathrm{Be}, \mathrm{Ga}, \mathrm{La}$ and $\mathrm{V}$, markedly different findings have been reported by other research groups. The reasons for these differences should be determined by further investigation. Studies could be extended to other as yet unexplored elements, for example, the majority of the lanthanides, the five remaining metalloids, most of the transition metals and the Group 5 metal Bi. At present, more metals are unstudied than studied. Highly sensitive ICP-MS is the chemical analysis method of choice. There is a lack of toxicity data in plants for many elements. Further studies are needed to correct this problem. Our studies have concentrated on relatively clean sites. Research can be extended to more contaminated venues. The type of soil could be a factor in elemental uptake by the date palm. Our studies have focused on Haplic Torriarents soil. Further work could be performed on other soil types. The Fard cultivar of the date palm was considered by the authors. Research should be extended to other cultivars, since what happens in one variety does not guarantee the same behavior in a different one.

\section{Acknowledgements}

The authors would like to thank the students, staff and faculty of Sultan Qaboos University, Sultanate of Oman 
for their assistance.

\section{REFERENCES}

[1] S. M. Al-Shayeb, M. A. Al-Rajhi and M. R. D. Seaward, "The Date Palm (Phoenix Dactylifera L.) as a Biomonitor of Lead and Other Elements in Arid Environments," Science of the Total Environment, Vol. 168, No. 1, 1995, pp. 1-10. doi:10.1016/0048-9697(95)04556-G

[2] W. H. Barrevel, FAO Agricultural Service Bulletin (Rome), 1993, p. 101.

[3] S. M. Al-Shayeb, "Comparison Study of Phoenix Dactylifera L. and Nerium Oleander L. as Biomonitors for Lead and Other Elements," Asian Journal of Chemistry, Vol. 14, No. 2, 2002, pp. 597-601.

[4] A. K. Yousif, N. D. Benjamin, A. Kado, S. M. Alddin and S. M. Ali, "Chemical Composition of Four Iraqi Date Cultivars," Date Palm Journal, Vol. 1, No. 2, 1982, pp. 285-294.

[5] W. N. Sawaya, H. A. Khatchadourian, J. K. Khalil, W. M. Safi and A. Al-Shalhat, "Growth and Compositional Changes during the Various Development Stages of Some Saudi Arabian Date Cultivars," Journal of Food Science, Vol. 47, No. 9, 1982, pp. 1489-1497.

doi:10.1111/j.1365-2621.1982.tb04967.x

[6] C. Smith and H. Farrankop, "Vitamin Contents of 15 Varieties of Arizona Dates," Report of the Arizona Agricultural Experiment Station, No. 69, 1945.

[7] E. G. Zook, "Mineral Composition of Fruits," Journal of the American Dieticians' Association, Vol. 53, No. 6, 1968, pp. 588-591.

[8] A. Aksoy and M. Ozturk, "Phoenix Dactylifera L. as a Biomonitor of Heavy Metal Pollution in Turkey," Journal of Trace and Microprobe Techniques, Vol. 14, No. 3, 1996, pp. 605-614.

[9] A. H. Bu-Olayan and B. V. Thomas, "Biomonitoring Studies on the Effect of Lead in Date Palm (Phoenix dactylifera) in the Arid Ecosystem of Kuwait," Journal of Arid Environments, Vol. 51, No. 1, 2002, pp. 133-139. doi:10.1006/jare.2001.0916

[10] A. L. Al-Khlaifat and O. A. Al-Khashman, "Atmospheric Heavy Metal Pollution in Aqaba City, Jordan, Using Phoenix Dactylifera L. Leaves," Atmospheric Environment, Vol. 41, No. 39, 2007, pp. 8891-8897. doi:10.1016/j.atmosenv.2007.08.028

[11] J. B. Jones Jr., "Plant Nutrition Manual," CRC Press, New York, 1998.

[12] A. J. Shaw, "Heavy Metal Tolerance in Plants: Evolutionary Aspects," CRC Press, Boca Raton, 1989.

[13] H. Jonkers, "Biennial Bearing in Apple and Pear: A Literature Survey," Scientia Horticulturae, Vol. 11, No. 4, 1979, pp. 303-317. doi:10.1016/0304-4238(79)90015-3

[14] G. M. Gadd and A. J. Griffiths, "Microorganisms and Heavy Metal Toxicity," Microbial Ecology, Vol. 4, 1978, pp. 303-317. doi:10.1007/BF02013274

[15] T. Duxbury, "Ecological Aspects of Heavy Metal Responses in Microorganisms," In: K. C. Marshall, Ed., Ad- vances in Microbial Ecology, Plenum Press, New York, 1985, p. 185.

[16] C. Sorentino, "The Effects of Heavy Metals on Phytoplankton: A Review," Phykos, Vol. 18, 1979, pp. 149161.

[17] L. C. Rai, J. P. Gaur and H. D. Kumar, "Phycology and Heavy Metal Pollution," Biological Reviews of the Cambridge Philosophical Society, Vol. 56, 1981, pp. 99-151. doi:10.1111/j.1469-185X.1981.tb00345.x

[18] M. Awadallah, A. H. Amrallah and F. Grass, "Environmental and Chemical Studies on Trace Element Levels in Some Egyptian Fruit and Condiments," In: Environmental Radiochemical Analysis, The Royal Society of Chemistry, Cambridge, 1999, pp. 330-342.

[19] J. R. Williams, A. E. Pillay, M. O. El Mardi, S. M. H. Al-Lawati and A. Al-Hamdi, "Levels of Selected Metals in the Fard Cultivar (Date Palm)," Journal of Arid Environments, Vol. 60, No. 2, 2005, pp. 211-225. doi:10.1016/j.jaridenv.2004.04.005

[20] A. K. De, "Environmental Chemistry," Wiley Eastern Ltd., New Delhi, 1990.

[21] N. I. Ward, "Trace Elements," In: F. W. Fifield and P. W. Haines, Eds., Environmental Analytical Chemistry, Blackwell, Oxford, 2000, pp. 360-392.

[22] M. Kalin and P. M. Stokes, "Macrofungi on Uranium Mill Tailings - Associations and Metal Content," Science of the Total Environment, Vol. 19, 1981, pp. 83-94. doi:10.1016/0048-9697(81)90120-0

[23] S. Manahan, "Environmental Chemistry," Lewis, London, 1994.

[24] I. Pulford and H. Flowers, "Environmental Chemistry at a Glance," Blackwell, Oxford, 2006.

[25] J. B. Jones Jr., B. Wolf and H. A. Mills, "Plant Analysis Handbook," Micro-Macro Publishers, Georgia, USA, 1991, pp. 75-76.

[26] C. Baird, "Environmental Chemistry," Freeman, New York, 1999.

[27] A. Marzec and R. Bulinski, "Content of Selected Elements in Dried Fruits," Bromatologia i Chemia Toksykologiczna, Vol. 30, No. 1, 1997, pp. 75-78.

[28] E. W. A. Mofida, "Determination of Some Toxic Elements in Local Foodstuff of Saudi Arabia Kingdom Using Atomic Absorption Spectroscopy," Journal of the Saudi Chemical Society, Vol. 6, 2002, pp. 7-14.

[29] A. E. Pillay, J. R. Williams, S. M. Hassan, M. O. El Mardi and A. Al-Hamdi, "Monitoring of Cadmium in 'on' and 'off' Date Palms," Environment International, Vol. 28, No. 4, 2002, pp. 273-276. doi:10.1016/S0160-4120(02)00034-X

[30] S. E. Waheed, N. Siddique, A. Rahman, S. Saeed, J. H. Zaidi and S. Ahmad, "INAA and ETAAS of Toxic Element Content of Fruits Harvested and Consumed in Pakistan," Journal of Radioanalytical and Nuclear Chemistry, Vol. 262, No. 3, 2004, pp. 691-696.

[31] I. M. Aldjain, M. H. Al-Whaibi, S. S. Al-Showiman and M. H. Siddiqui, "Determination of Heavy Metals in the 
Fruit of Date Palm Growing at Different Locations of Riyadh," Saudi Journal of Biological Sciences, 2011, in Press. doi:10.1016/j.sjbs.2010.12.001

[32] S. M. Al-Shayeb and M. R. D. Seaward, "The Date Palm (Phoenix dactylifera L.) Fibre as a Biomonitor of Lead and Other Elements in Arid Environments," Asian Journal of Chemistry, Vol. 12, No. 4, 2000, pp. 954-966.

[33] A. E. Pillay, J. R. Williams, M. O. El Mardi, S. M. H. Al-Lawati, M. H. Al-Hadabbi and A. Al-Hamdi, "Risk Assessment of Chromium and Arsenic in Date Palm Leaves Used as Livestock Feed," Environment International, Vol. 29, 2003, pp. 541-545. doi:10.1016/S0160-4120(03)00011-4

[34] L. P. Gough, L. L. Jackson and J. A. Sacklin, "Determining Baseline Element Composition of Lichens. II. Hypogymnia Entermorpha and Usnea spp. at Redwood National Park, California," Water Air and Soil Pollution, Vol. 38, 1988, pp. $169-180$.

[35] I. Olmez, M. C. Gulovali and G. E. Gordon, "Trace Element Concentrations in Lichens near a Coal-Fired Power Plant," Atmospheric Environment, Vol. 19, No. 10, 1985, pp. 1663-1669. doi:10.1016/0004-6981(85)90218-5

[36] S. Smith, "Ecological and Health Effects of Chemical Pollution," In: R. M. Harrison, Ed., Understanding Our Environment - An Introduction to Environmental Chemistry and Pollution, The Royal Society of Chemistry, Cambridge, 1999.

[37] J. R. Williams, A. E. Pillay and B. Yaghi, "Date Palm Leaflets: Bioindicators of Total Mercury in Soil and Assessment of the Potential for Biomagnification of Total Mercury along a Food Chain," Research Journal of Chemistry and Environment, Vol. 12, No. 2, 2008, pp. 27-29.

[38] N. Krasnow, "Effects of Lanthanum and Gadolinium Ions on Cardiac Sarcoplasmic Reticulum," BBA - Biomembranes, Vol. 282, 1972, pp. 187-194.

[39] N. Krasnow, "Lanthanide Inhibition of Calcium Binding by Muscle Microsomes: ATP and Time Dependency," Journal of Molecular and Cellular Cardiology, Vol. 10, No. 1, 1978, pp. 55-66. doi:10.1016/0022-2828(78)90006-8

[40] T. Funakoshi, K. Furushima, H. Shimada and S. Kojima, "Anticoagulant Action of Rare Earth Metals," Biochemical International, Vol. 28, 1992, pp. 113-119.

[41] V. G. Grivennikova, E. V. Gavrikova and A. D. Vinogradov, "An Increase of the Energy Coupling Capacity of Submitochondrial Particles by Lanthanides," FEBS Letters, Vol. 347, No. 2-3, 1994, pp. 243-246. doi:10.1016/0014-5793(94)00541-9

[42] H. Liu, L. Yuan, X. Yang and K. Wang, " $\mathrm{La}^{3+}, \mathrm{Gd}^{3+}$ and $\mathrm{Yb}^{3+}$ Induced Changes in Mitochondrial Structure, Membrance Permeability, Cytochrome $c$ Release and Intracellular ROS Level," Chemico-Biological Interactions, Vol. 146 , No. 1, 2003, pp. 27-37. doi:10.1016/S0009-2797(03)00072-3

[43] L. Feng, H. Xiao, X. He, Z. Li, F. Li, N. Liu, Z. Chai, Y. Zhao and Z. Zhang, "Long-Term Effects of Lanthanum
Intake on the Neurobehavioral Development of the Rat," Neurobehavioral Toxicology and Teratology, Vol. 28, No. 1, 2006, pp. 119-124. doi:10.1016/j.ntt.2005.10.007

[44] L. Feng, H. Xiao, X. He, Z. Li, F. Li, N. Liu, Y. Zhao, Y. Huang, Z. Zhang and Z. Chai, "Neurotoxicological Consequence of Long-Term Exposure to Lanthanum," Toxicology Letters, Vol. 165, 2006, pp. 112-120. doi:10.1016/j.toxlet.2006.02.003

[45] A. E. Pillay, J. R. Williams, T. Khan, S. Al-Saidi and B. Yaghi, "Elevated Levels of Rare Earths from Sewage Plant Attached to Hospital Complex," Research Journal of Chemistry and Environment, Vol. 13, No. 2, 2009, pp. 93-95.

[46] R. N. Reeve, "Environmental Analysis," Wiley, Chichester, 1994.

[47] S. M. Al-Shayeb and M. R. D. Seaward, "Sampling Standardisation of Date Palm (Phoenix Dactylifera L.) Leaflets as a Biomonitor of Metal Pollutants in Arid Environments," Asian Journal of Chemistry, Vol. 12, No. 4, 2000, pp. 977-989.

[48] S. M. Al-Shayeb, "Lead and Other Elements in Date Palm (Phoenix Dactylifera L.) Fruits (Dates)," Asian Journal of Chemistry, Vol. 14, No. 2, 2002, pp. 577-582.

[49] J. R. Williams and A. E. Pillay, "Monitoring Nickel Uptake in Date Palms from Nickel-Contaminated Soil," Research Journal of Chemistry and Environment, Vol. 13, No. 2, 2009, pp. 5-9.

[50] A. L. J. Peter and T. Viraraghavan, "Thallium: A Review of Public Health and Environmental Concerns," Environment International, Vol. 31, 2005, pp. 493-501. doi:10.1016/j.envint.2004.09.003

[51] B. Mukherjee, B. Patra, S. Mahapatra, P. Banerjee, A. Tiwari and M. Chatterjee, "Vanadium - An Element of Atypical Biological Significance," Toxicology Letters, Vol. 150, No. 1, 2004, pp. 135-143. doi:10.1016/j.toxlet.2004.01.009

[52] S. S. Zumdahl and S. A. Zumdahl, "Chemistry," Houghton Mifflin, New York, 2007.

[53] A. E. Pillay, J. R. Williams, S. M. Hassan, M. O. El Mardi and A. Al-Hamdi, "Boron and the Alternate- Bearing Phenomenon in the Date Palm (Phoenix Dactylifera)," Journal of Arid Environments, Vol. 62, No. 2, 2005, pp. 199-207. doi:10.1016/j.jaridenv.2004.11.007

[54] E. Epstein, "The Anomaly of Silica in Plant Biology," Proceedings of the National Academy of Science USA, Vol. 91, 1994, pp. 11-17. doi:10.1073/pnas.91.1.11

[55] M. Radojević and V. N. Bashkin, "Practical Environmental Analysis," The Royal Society of Chemistry, Cambridge, 1999.

[56] M. O. El Mardi, S. B. Salama, E. C. Consolacion and M. Al-Solomi, "Effect of Treated Sewage Water on the Concentration of Certain Nutrient Elements in Date Palm Leaves and Fruits," Communications in Soil Science and Plant Analysis, Vol. 29, No. 5-6, 1998, pp. 763-776. doi:10.1080/00103629809369983

[57] D. C. Harris, "Quantitative Chemical Analysis," Freeman, New York, 1999. 